Maria Eva Rosalyn, Master of Arts in Communication

e-mail: evayorian@gmail.com

Dwinanto Kurniawan, Master of Arts in Communication

e-mail:dwinanto@polytama.co.id

London School of Public Relations, Jakarta, Indonesia

\title{
THE SOLUTION TO THE PLASTIC USAGE PROBLEMS; A STRONG CAMPAIGN FOR INNOVATIVE WASTE MANAGEMENT
}

\begin{abstract}
Plastic pollution has become a huge environmental problem, prompting some cities and countries to heavily tax or ban the plastics products such as bags and straws. Hence, the purpose of this research is to provide knowledge into the effectiveness of campaigns using plastic and plastic waste, and provide an overview of a new innovative waste management. This research is also intended to introduce Masaro (Zero Waste Management), a CSR program at Polytama Company, as it would be an innovative and efficient waste management instead a massive campaign.
\end{abstract}

Keywords: plastic; waste management; zero waste; environment

\section{Introduction}

Environmental pollution, global warming, climate change, biodiversity and natural resources degradation are environmental issues that have awakened human consciousness to the importance of environmental sustainability for human wellbeing. A massive PR campaign on plastic waste has been raised since over 50 years ago.

Public Relations Campaign inside specific meaning aims to increase awareness and knowledge of the target audience. In addition, it aims to grab attention and foster perception or a positive opinion of an activity from an institution or organization (corporate activities) in order to create a good image from the community through the delivery of messages intensive with the communication process and time period certain sustainable ones. In a more general or broad sense, according to R.A Sentosa Satroepoetra, public relations campaign provides continuous lighting as well understanding and motivation of the community towards a certain program activities through processes and continuous communication techniques and plan to achieve publicity and image.

According to Leslie B. Snyder (2002) broadly speaking, the campaign communication is a communication activity organized, directly directed at the audience certain, at a predetermined time period to achieve certain goals. Besides the campaign public relations is done in a planned, systematic manner motivating, psychological and done repeatedly and continuously. PR campaigns raise some issues which are including developing among the people at the time this done by many companies or organizations.

PR from companies and organizations willing to take part in communicating the issue of plastic waste to the community and strive to grow public awareness to understand more about issues and together take part in looking for solution to the problem/issue. According to Keith Davis, participation is a matter of a person's

(C) M. E. Rosalyn, D. Kurniawan, 2019 
mental and emotional involvement in group situation that drives them to contribute to group goals and together responsible for the goal that is; Community participation is very important in the success of an action or event. Without participation from the target or the community concerned, a goal is not will be achieved. Like the campaign on plastic waste. The purpose of this campaign will not be achieved without participation from the community.

Hundreds of Non-Governmental Organizations around the world have already realized the detrimental impact of plastic pollution on our world. As such, they are working hard to prevent and eliminate it. Below are some the organizations that are working in the area and the actions that they are taking.

\section{One Green Planet}

An independent online platform, One Green Planet provides readers with information on sustainable, everyday habits. They are the instigators of the \#CrushPlastic Movement. This campaign focuses on reducing single-use plastics including shopping bags, coffee cups, water bottles, take out containers, and straws.

\section{Clear Blue Sea}

This relatively new, not-for-profit the Clear Blue Sea, is actively working to rid oceans of plastic and repurposing the plastic that they collect. Their innovative solution uses a Floating Robot for Eliminating Debris (FRED). Not only does it clean up debris, but it also uses renewable energy, has a self-preservation mechanism during storms, and can help rescue animals trapped in debris.

\section{Earth Day Network}

What started as a small network during the first Earth Day, the Earth Day Network now has over 50,000 partners globally. The organization is focused on promotion and awareness, particularly for Earth Day itself. They create important campaigns and materials including this Plastic Pollution Primer and Action Toolkit. Those Non-Governmental Organizations bring up the same message, to reduce the plastic use.

Campaign is a communication activity which peaks in a certain period of time in order to influence a society (Sastropoetro (1983: 99). Meanwhile, according to communication expert Rice and Paisley in Ruslan (2002: 58), said that one's desire to influence opinion individual and public, trust, behavior, interest and the wishes of the audience with the attractiveness of the communicator which is also communicative.

Plastics are man-made organic materials that are produced from oil and natural gas as raw materials. They are relatively cheap, durable and versatile material. Products made from plastics have brought benefits to society in terms of economic activity, jobs and quality of life. Plastics can even help reduce energy consumption and greenhouse gas emissions in many circumstances, even in some packaging applications when compared to the alternatives (European commission Directorate General for Environment, 2011). The benefits driven from plastics compel manufacturers to increase production. 
FOEN (2003) indicates that, plastics form around 15\% of household refuse and according to a report published in December 2010, the United States Environmental Protection Agency (USEPA) determined that, the United States alone generated 30 million tons of plastic waste in 2009. It is believed after their entry into the environment, plastics can persist up to 100 years without being decomposed by sunlight and/or microorganisms (Stevens, 2001 and United Nations Environment Programme, 2005a).

The issue of plastic waste management is therefore a major global phenomenon that has crept up over the decades, and really requires a global and comprehensive solution that includes systemic rethinks about usage, production and recycles. It is a crucial problem not only for developing countries but for the developed countries as well.

The message is made in such a way and always interesting attention. The message is formulated through symbols which are easy to understand or understand communicant.

Campaign on plastic problems has been launch massively around the world, but in fact the plastic problem has not got the clear of point. The campaign itself has been supported by the Government. In some area in Indonesia, Regional Regulations has been applied to control the plastic use. The Bali Provincial Government prohibits various components and communities in the area from using disposable plastic, along with the issuance of the Bali Governor Regulation Number 97 of 2018. In the Bali's Governor Regulation Number 97 Year 2018 concerning the Limitation of Disposable Plastic Waste that has been issued on December 21, there are three ingredients that are made of or contain prohibited plastic ingredients, namely plastic bags, polystyrene, and plastic straws.

There is a decisive condition the success or failure of a campaign, according to Wilbur Schramm is quoted in Rosady Ruslan's book Public Relations Research Methods, the coalition supporting the success or failure of delivering messages inside campaigning is as follows.

Many municipalities, cities and towns the world over continue to grapple with the problem because it imposes negative environmental externalities. It is usually non-biodegradable and therefore can remain as waste in the environment for a very long time, it may pose risks to human health as well as the environment; and it can be difficult to reuse and/or recycle in practice. The campaign on plastic shouldn't only focusing to "not to use" plastic, instead build awareness on the plastic waste management, plastic used plastic through a recycle process could be made into higher-value products.

\section{Analysis}

Since 2004, the world has made a huge amount of plastic as it did in the previous half century, and it has been reckoned that the total mass of virgin plastics ever made amounted to 8.3 billion tons. It is mainly derived from natural gas and crude oil, used as chemical feedstock and fuel sources. In 2015, $407 \mathrm{Mt}$ of plastics was produced, of which $164 \mathrm{Mt}$ was consumed by packaging (36\% of the total). It appears that, of all the plastics produced to date, 2.5 billion tons (30\%) are currently in use, and between 1950 and 2015, the cumulative generation of primary and secondary (recycled) plastic waste amounted to 6.3 billion tons, of which $9 \%$ had been recycled 
(just $10 \%$ of this having been recycled more than once), $12 \%$ incinerated, and the remaining $79 \%$ either ended up in landfills or in the natural environment.

Although it has been quoted values vary, packaging probably accounts for around one third of all plastic used, of which approximately $40 \%$ goes to landfill, while $32 \%$ escapes the collection system: that is, either it is not collected at all, or is collected but then illegally dumped or mismanaged, and ends up directly in the environment. Only $28 \%$ of packaging waste had been collected, of which half was incinerated to provide energy, while the other half was recycled. The prognosis is that, should current trends maintain, by 2050 there will be of the order of 12 billion tons of plastic waste either in landfills or in the natural environment, and more plastic than fish in the seas (by mass). It was deduced that around $9 \mathrm{Mt}$ of plastic entered the oceans in 2010 , as a result of mismanaged waste, along with up to $0.5 \mathrm{Mt}$ each of micro plastics from washing synthetic textiles, and from the abrasion of tires on road surfaces. It is estimated that in the region of $2 \mathrm{Mt}$ of plastic pollution is delivered to the oceans by rivers, each year.

According to Spokas (2007) and Geographical (2005) around 500 billion of plastics bags are used worldwide. A United Kingdom group Waste online also puts annual global production of plastic around 100 million tons per year. In a study conducted in Switzerland in 2010, approximately 1000,000 tons or $125 \mathrm{~kg}$ of plastic material was used or consumed per head. According to the same report, the world produces 20 times more plastic today than 50 years ago (Federal Office of the Environment, 2003). As plastic consumption is increasing, more and more plastic waste is being generated (World Bank, 1996; Yankson, 1998). In 2018, the use of plastic in South Tangerang is still dominant. Every day, plastic waste produced from the city of South Tangerang reaches 105.5 tons. Head of South Tangerang Waste Department, Wismansyah explained that the daily waste production in the city of South Tangerang reaches 890 tons. This amount is dominated by household and industrial waste up to 700 tons per day. While plastic waste fills 11.86 percent of total waste in South Tangerang. Plastic is 11.86 percent contributing to the volume of waste in South Tangerang.

Professor of Air and Waste Management at the Bandung Institute of Technology (ITB), Prof. Dr. Enri Damanhuri, said that each year around 44 percent of plastic waste is 2.13 million tons of polluted environments. He said, of the total national plastic waste, only 36 percent could be collected and collected by the Sanitation Office and Environmental Agency and disposed of to the Trash Disposal Site (TPA). Furthermore, only 20 percent has entered the informal system, such as garbage banks to be recycled, and other 44 percent fled to the environment (Embu, S. W., ITB Noted 2,13 Million Plastic Waste Per Year Cemari Indonesia, accessed on www.merdeka.com, 2018).

As enormous amount of plastic waste is generated throughout the world, the most crucially posed question is how to manage it effectively and efficiently to save the environment and the continuous existence of mankind (Wienaah, 2007).

Four of Indonesia's rivers rank among the 20 most polluted in the world in terms of mismanaged plastic waste measured in metric tons. This makes Indonesia the second-largest contributor to marine plastic pollution after China. A recent research article, published in the journal Nature Communications, estimates that between 1.15 million and 2.41 million tons of plastic enters the oceans every year from rivers. In this case, Indonesia is estimated to emit around 200,000 tons of plastic from rivers and streams, mainly from Java and Sumatra. Plastic debris can kill marine animals 
that get entangled and drown or starve after they ingest particles they cannot digest. Toxins leach from plastic as it breaks down, posing health risks for animals, while also entering the food chain and eventually ending up on our plates.

\section{Global mismanaged plastic by region, 2010}

Share of global mismanaged plastic waste by region in 2010. This is measured as the total mismanaged waste by populations within $50 \mathrm{~km}$ of the coastline, and therefore defined as high risk of entering the oceans. Mismanaged plastic waste is defined as "plastic that is either littered or inadequately disposed. Inadequately disposed waste is not formally managed and includes disposal in dumps or open, uncontrolled landfills, where it is not fully contained. Mismanaged waste could eventually enter the ocean via inland waterways, wastewater outflows, and transport by wind or tides."

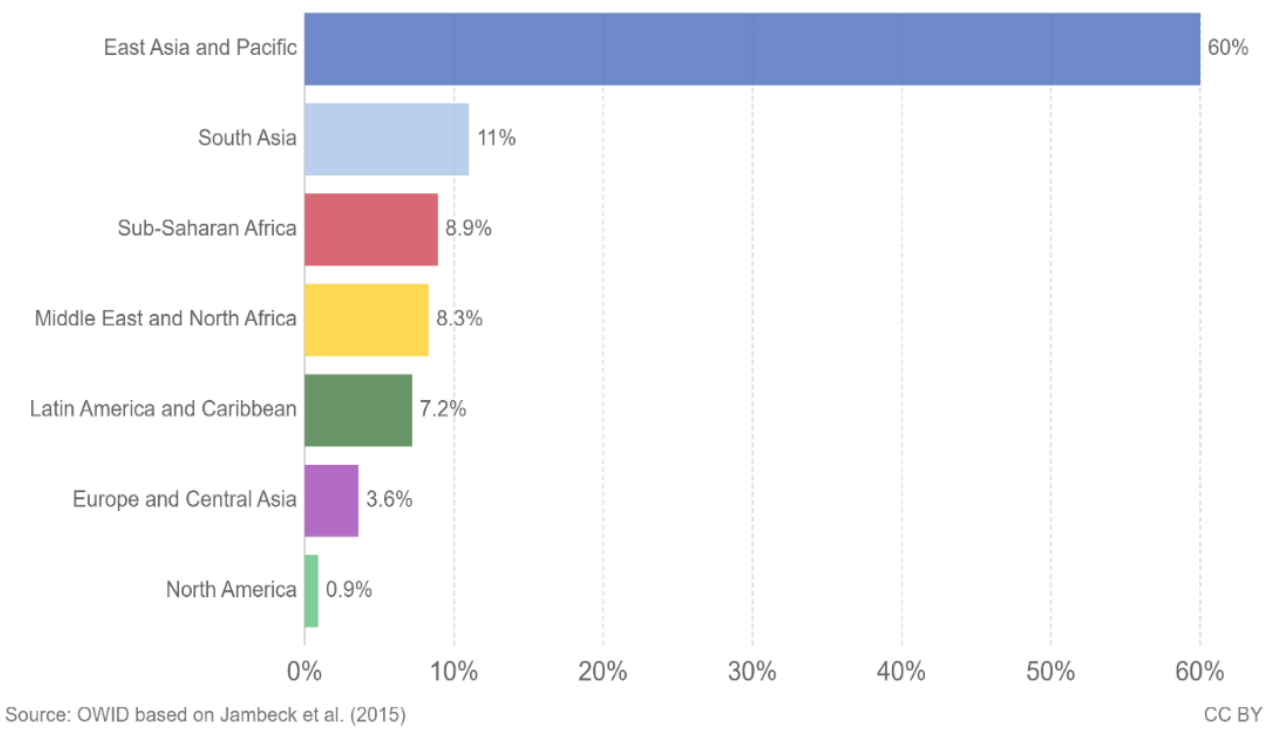

Figure 1 - Global Mismanaged Plastic in 2010

Community awareness about the hazards of plastic waste is important. But it's likely to do a realistic action on the plastic waste management, as what Polytama Company did through their CSR program.

Polytama Propindo Company is one of the largest polypropylene (PP resin) producing companies in Indonesia which was established in 1993. Polytama has a Plant located in Limbangan Village, Juntinyuat District, Indramayu, West Java. Polytama Propindo Company as a company around Indramayu Regency is obliged to embrace local residents by collaborating to conduct programs that need to be disseminated to residents around the Industrial area. As one of the big industries that produce polypropylene (plastic), Polytama Propindo Company has an obligation to run a CSR (Corporate Social Responsibility) program. One of the problems of the community that touches on PT Polytama Propindo's core business is plastic waste. The problem of plastic waste arises from an increase in the amount of landfill that is not handled by good waste management, resulting in a lot of plastic waste that is not managed and ultimately results in other problems such as flooding, air pollution and environmental pollution. Many assume that plastic is un-environmentally friendly and takes a long time to completely decompose. Even though the fact is that the habit of littering and poor waste management is what causes environmental pollution. Plastic waste and decaying waste are often mixed together, making it difficult to recycle. This is due to the lack of a good waste management system. By handling 
the right waste such as MASARO (Zero Waste Management), plastic waste can be transformed into things that have use and economic value because of their ability to be recycled to the maximum.
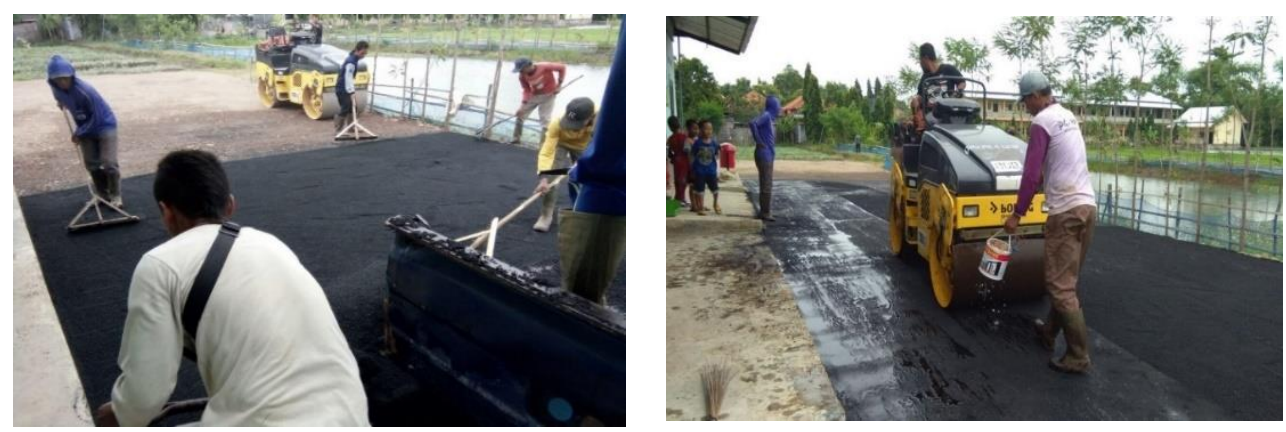

Figure 2 - The Asphalt Process by using recycled materials

MASARO (Zero Waste Management) program is designed to overcome community waste management problems, including plastic waste, whose implementation is not only an activity that gives a momentary impact, but is a longterm solution that benefits the village community, which is currently focused on Tinumpuk Village, Juntinyuat District, Indramayu Regency. For this program Polytama Propindo Company collaborated with the ITB Polymer and Membrane Technology Laboratory (LTPM-ITB) and the Indramayu Regency Environmental Agency to start the Pilot Project as a pioneer of Zero Waste Management program (MASARO). This program is a great innovation that is expected to be emulated by other companies that also have the same concern and can continue to grow to the national scale. Located in Tinumpuk Village, Indramayu Regency, which is adjacent to the Polytama Propindo Company plant site area. This program is carried out by utilizing the waste in Tinumpuk Village into something that has benefits for its citizens. Through this program, it is expected to be an example for other regions in Indonesia. Waste management in Tinumpuk Village is still done in a conventional way, namely by burning garbage in front of each residence. The remaining ash from the combustion was left alone. Along the road in the village of Tinumpuk there are many scattered garbage, such as baby diapers that are thrown away. The level of cleanliness in Tinumpuk Village is still very low. One of the critical locations where many piles of illegally dumped waste are found on the riverbanks which cause blockages in the river channel and increase the risk of flooding.

Since the program's inauguration on January 25, 2018, the MASARO program in Tinumpuk Village has been going well. Proper waste management makes waste have economic value that is beneficial for the villagers. As with decaying waste which is processed into liquid fertilizer, fuel oil produced from processing plastic waste and residual combustion fuel can be used as a fertilizer mixture. The product legality of the MASARO program in the form of liquid fertilizer and fuel oil is being pursued by Polytama Propindo Company and assisted by the Department of Living Environment of Indramayu Regency. All recycled products from MASARO have useful and economical value. Some of the products from processed waste are substitute for kerosene, highway reinforcement which can indirectly reduce production costs in paving, and liquid fertilizer as animal feed that can be resold by 
the people of Tinumpuk Village. To support the sustainability of this program, educational programs are also carried out by striving for the availability of adequate discharged landfill facilities, both in homes, markets, offices, and other public places. In addition, the garbage collection system must also be carried out in a separate manner. Certain rubbish must be collected on certain days and certain places consistently, regularly and continuously. Therefore, all components of society must change their life habits so that they are accustomed to sorting out waste when disposing of it or having to do socialization and education activities so that people are more accustomed to sorting waste.

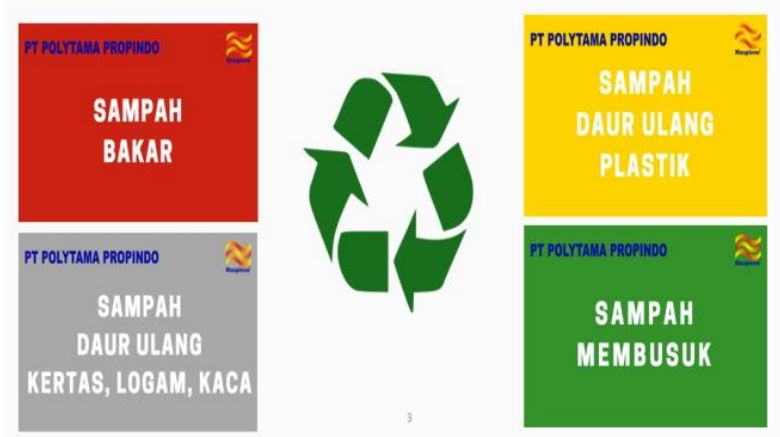

Figure 3 - Distribution of types of waste from the MASARO program

Recycled waste in the form of plastic, glass, cans, and paper is collected and placed in front of the house which is then taken by scavengers and then sold to the waste recycling industry. Meanwhile, fuel waste in the form of paper is not feasible to use, wood chips, boxes that cannot be sold are burned by the people themselves in the incinerator at the region level.

Waste is divided into four types, namely rotting garbage, plastic waste, recycled waste (paper, metal, glass), and fuel waste. In order to make sorting easier, segregated trash cans are distributed to the houses of the Tinumpuk Villages. Segregation will be carried out by the people in their respective homes, then officers from the Waste Bank "CBO Ibu Tin Berseri" will pick up garbage to rot every three days, and other types of garbage every once a week. Disaggregated waste is then collected at the Waste Bank "CBO Ibu Tin Berseri".

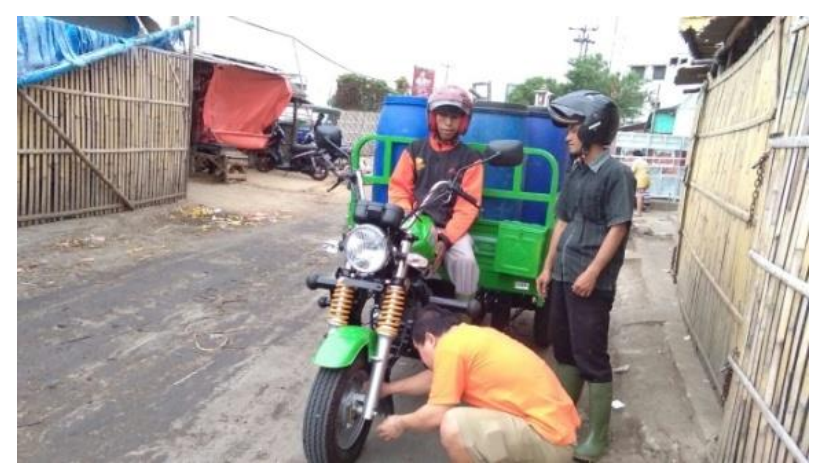

Figure 4 - The motorbike carrying garbage transports residents' garbage to 
Arriving at the "CBO Ibu Tin Berseri" the collected waste is weighed first and then placed on the basis of the type of waste for further management using waste processing equipment, namely in the form of pyrolyzators, incinerators and several other tools. Combustion of plastic waste carried out at low temperatures in the open space produces carcinogenic hazardous compounds such as polychloro dibenzo dioxins and polychloro dibenzo furans. But with the presence of pyrolyzators, plastic waste can be processed into oil fuel which has economic value. Meanwhile, processing decomposed waste is carried out behind the eastern part of the CBO building. Rubbish-decaying waste is transferred into other containers after being given liquid to ferment.

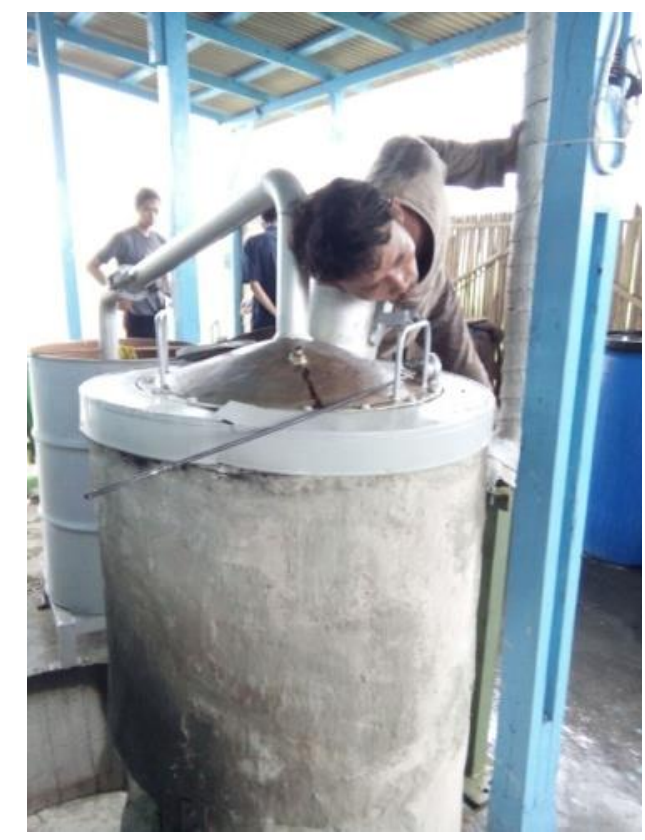

Figure 5 - Pirolisator found at "Community Base Organization (CBO) Ibu Tin Berseri”

The final processing of waste which cannot be composted and recycled is by burning it in an incinerator. Incineration is the process of combustion of waste with the amount of excess oxygen, which converts waste bait into ash, money gas and particulates. Bait waste that can be processed consists of fuel waste (twigs, paper that cannot be recycled, the rest of cloth and wood) and garbage B2. Processing with this method is very effective in reducing the volume of waste that cannot be recycled until it reaches 95-96\%. Incineration can significantly reduce landfill land use or landfill (Final Disposal). The remaining ash from waste processing in an incinerator can be used to improve the production of BBM (Oil Fuel).

In addition to pyrosilators and incinerators, the "CBO Ibu Tin Berseri" Waste Bank also has an extruder to produce plastic seeds that have been collected from residents. Waste Bank "CBO Ibu Tin Berseri" has also carried out decomposing waste management by making Kasting (Compost Worm). The results of this Kasting are compost which can be used as red ginger compost.

To support the sustainability of this program, educational programs are also carried out by striving for the availability of adequate discharged landfill facilities, 
both in homes, markets, offices, and other public places. In addition, the garbage collection system must also be carried out in a separate manner. Certain rubbish must be collected on certain days and certain places consistently, regularly and continuously. Therefore, all components of society must change their life habits so that they are accustomed to sorting out waste when disposing of it or socialization and education must be carried out so that people are more accustomed to sorting waste.

The running and success of the MASARO program is the result of the collaboration between PT Polytama Propindo and Polymer Technology and Membrane Laboratory-Bandung Institute of Technology which in the future can be a form of ongoing CSR program collaboration. Polytama Propindo Company also always coordinates with Polymer Technology and Membrane Laboratory-Bandung Institute of Technology to do mapping in 3 villages closest to the Plant Site area, namely Tinumpuk Village, Lombang Village, and Limbangan Village.

As the company's Corporate Social Responsibility program goes on to the villages, of course the involvement of the local village head is much needed, one of the goals of this Corporate Social Responsibility program is to do empowerment aimed at the independence of the village community. Polymer Technology and Membrane Laboratory-Bandung Institute of Technology led by Dr. Zainal Abidin told Polytama Propindo Company that he was trying to submit a number of proposals in the scope of the Indramayu Regional Government and hoped for a positive response from the Regional Government.

In addition, further renovation activities in the MASARO area of Tinumpuk Village are also in talks to ensure the sustainability of this program. In the future, Polytama Propindo Company collaborates with the Ministry of Industry and the Ministry of Village to obtain a license in order to achieve Blue to Green PROPER (Performance Rating Assessment Program) and continue to Gold. In achieving towards PROPER, Polytama Propindo Company plans to make the RPJM (Medium Term Development Plan) for the Environment for the next five years.

Through the MASARO program, the Tinumpuk villagers gain an understanding of the importance of proper waste management for environmental hygiene and health, the right way to handle it, and what can be done so that the community can contribute to maintaining environmental cleanliness. This program also helps improve the skills and productivity of the community. The existence of the MASARO program opens new employment opportunities for the community of Tinumpuk Village.

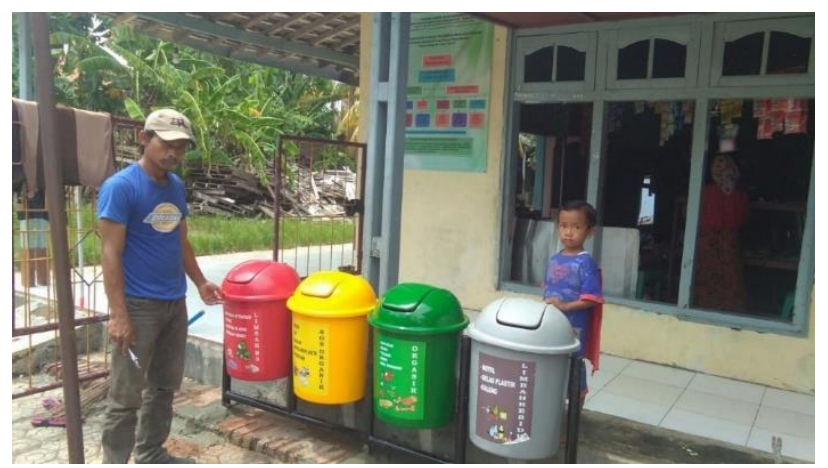

Figure 6 - The Tinumpuk villagers who use disaggregated trash cans 
All recycled products from MASARO have useful and economical value. Some of the products from processed waste are substitute for kerosene, highway reinforcement which can indirectly reduce production costs in paving, and liquid fertilizer as animal feed that can be resold by the people of Tinumpuk Village.
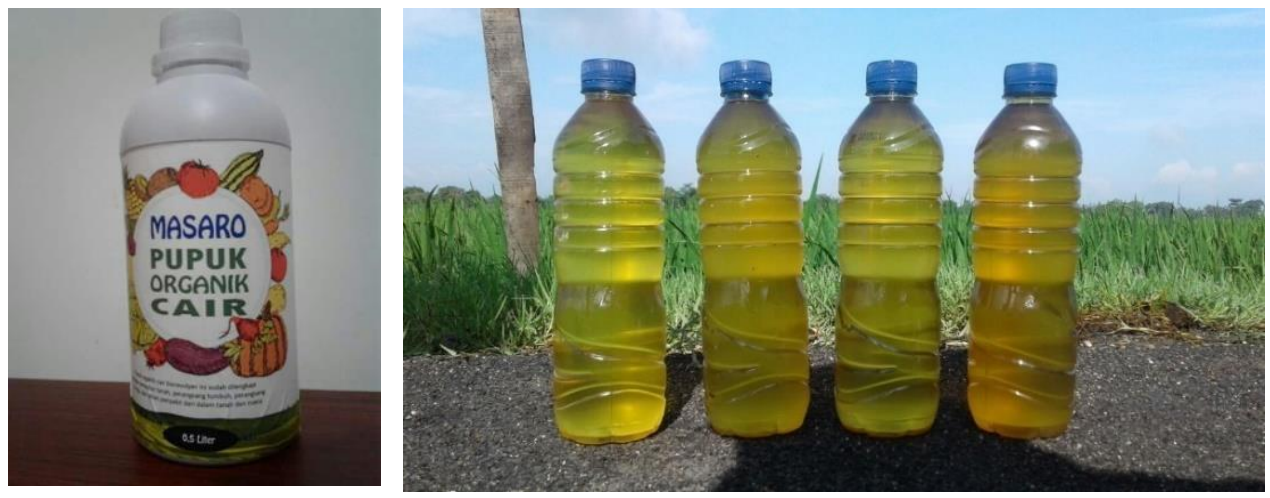

Figure 7 - Recycled products from Masaro

\section{Conclusion}

To win the battle against plastic pollution, the Indonesian central and regional governments need to strengthen their legal framework. Nationally applicable definitions are needed to distinguish between degradable plastic, recyclable plastic, biodegradable plastic and compostable plastic alternatives. There is a need to be clear about responsibility at each level of government and the creation of new norms, standards, procedures and criteria. The government must embark on a multi-tiered approach that engages affected communities. Those who continuously experience plastic pollution live with the urgency for action on a daily basis. The action taken may refer into a plastic waste management, recycle the plastic waste and change it into more valuable products, for a sustainable goal. Through Masaro program, Polytama Company builds a public knowledge that plastic waste is not something that is dangerous and threatens the health and sustainability of the environment. In fact, around us there are many found plastic-based waste which can actually be reprocessed into something that has benefits if proper handling is carried out starting from the community's own awareness.

\section{REFERENCES}

1. Adane, L., and Muleta, D. (2011). Survey on the usage of plastic bags, their disposal and adverse impacts on environment: A case study in Jimma City, Southwestern Ethiopia. Journal of Toxicology and Environmental Health Sciences, 3(8) pp. 234-248.

2. Embu, S. W., ITB Catat 2,13 Juta Sampah Plastik Tiap Tahun Cemari Indonesia, www.merdeka.com, 2018.

3. Ruslan, Rosady. Kiat dan Strategi Kampanye Public Relations, PT. Raja Grafindo. Jakarta: 1997.

4. Rusdianto, U. (2013). CSR Communicatons A Framework For PR Practicioners.

5. Snyder, Leslie. (2003). Development communication campaigns. Yogyakarta: Graha Ilmu. 
6. Werther, William B., Jr., and Keith Davis (1989). Human Resources and Personnel Management. 3, New York: McGraw- Hill.

7. World Bank (1996). Urban Environmental Sanitation Project, Staff Appraisal Report, Republic of Ghana, Africa Regional Office.

8. Yankson P. W. K. (1988). The Urban Informal Economy Accommodation, Growth, Linkages, Health and Environmental Impact. The Case of Greater Accra Metropolitan Area (GAMA). Ghana University Press, Accra.

The article was received 13.05.2019 and was accepted after revision 05.06.2019

\section{Марія Сва Розалін, Двінанто Курніаван}

ВИРІШЕННЯ ПРОБЛЕМИ ВИКОРИСТАННЯ ПЛАСТИКУ; ПОТУЖНА КАМПАНІЯ ЗА ІННОВАЦІЙНЕ УПРАВЛІННЯ ВІДХОДАМИ

Анотація. Забруднення пластиком стало величезною екологічною проблемою, що спонукало деякі міста та країни збільшувати оподаткування або забороняти деякі пластикові вироби, такі як пакети та соломинки. Отже, метою цього дослідження $\epsilon$ поширення знань задля підвищення ефективності кампаній за інноваційне управління пластиковими відходами, а також огляд цього інноваційного менеджменту відходів. Це дослідження також має на меті представити програму Масаро (Zero Waste Management), програму CSR компанії Polytama, оскільки це було б інноваційним та ефективним управлінням відходами.

Ключові слова: пластик; поводження з відходами; нульові відходи; навколишнє середовище

\section{Марія Єва Розалін}

магістр Лондонської школи зв'язків з громадськістю, Джакарта, Індонезія e-mail: evayorian@gmail.com

\section{Двінанто Курніаван}

магістр Лондонської школи зв'язків з громадськістю, Джакарта, Індонезія e-mail:dwinanto@polytama.co.id 